\title{
Temporally regulated overexpression of parathyroid hormone- related protein in the mammary gland reveals distinct fetal and pubertal phenotypes
}

\author{
M E Dunbar, P Dann, C W Brown, J Van Houton, B Dreyer, \\ W P Philbrick and J J Wysolmerski \\ Department of Internal Medicine, Yale University School of Medicine, New Haven, Connecticut, USA \\ (Requests for offprints should be addressed to J J Wysolmerski, Section of Endocrinology and Metabolism, Department of Internal Medicine, \\ Yale University School of Medicine, FMP 102, 333 Cedar Street, New Haven, Connecticut 06520, USA; Email: john.wysolmerski@yale.edu) \\ (M E Dunbar is now at Department of Biology, Pennsylvania State University, Berks Campus, Reading, Pennsylvania, USA)
}

\begin{abstract}
We have previously demonstrated that overexpression of parathyroid hormone-related protein (PTHrP) in the mammary glands of transgenic mice results in defects in ductal elongation and branching during puberty and in lobuloalveolar development during pregnancy. In addition, we have shown that PTHrP is necessary for the formation of the initial ductal tree during embryonic mammary development. In order to examine the effect of varying the timing of PTHrP overexpression on mammary development, we created tetracycline-regulated, K14tTA/ Tet $_{\mathrm{O}}-\mathrm{PTHrP}$ double transgenic mice. In this report, we document that this 'tet-off' system directs transgene expression to the mammary gland and that it is fully repressed in the presence of tetracycline. Using these
\end{abstract}

mice, we demonstrate that transient overexpression of PTHrP before birth causes defects in ductal branching during puberty and that overexpression of PTHrP during puberty decreases the rate of ductal elongation. Furthermore, we demonstrate that if $\mathrm{PTHrP}$ overexpression is initiated after ductal morphogenesis is completed, lobuloalveolar development is unaffected. Finally, we demonstrate that the impairment in ductal elongation caused by PTHrP is associated with an increase in the basal rate of epithelial cell apoptosis in terminal end buds and a failure to increase end bud cell proliferation and decrease apoptosis in response to estrogen and progesterone.

Journal of Endocrinology (2001) 171, 403-416

\section{Introduction}

The murine mammary gland forms in three distinct stages: during embryogenesis, during puberty, and during pregnancy/lactation (Daniel \& Silberstein 1987, Sakakura 1987, Hennighausen \& Robinson 1998). The embryonic phase begins with the budding of a bulb-shaped mammary anlage from the ventral epidermis between embryonic days 10 and 12 . This mammary bud subsequently grows out into a corner of a specialized stromal compartment known as the mammary fat pad and, by birth, a rudimentary ductal tree of approximately $15-20$ branches is formed. Little additional growth of the ducts occurs until the onset of puberty when they begin to extend and branch, eventually filling out the entire mammary fat pad. Growth occurs in a directed fashion away from the nipple region, and results from the formation of bulb-shaped structures called terminal end buds (TEBs) at the distal end of the epithelial ducts. These structures act as centers of epithelial proliferation, differentiation and apoptosis. At the end of puberty, when the ducts have reached the

borders of the fat pad, the TEBs regress and growth ceases. The next phase of mammary development occurs during pregnancy and only then does the fully differentiated, secretory epithelium form. As a result of hormonal changes, there is a proliferation of a large number of terminal ductules, followed by the development of lobuloalveoli. Towards the end of pregnancy, the alveolar epithelial cells become secretory and lactation is initiated at delivery. The cessation of lactation brings about massive apoptosis and remodeling of the lobuloalveolar structures, reverting the ductal architecture to one that resembles the virgin gland.

At all stages of its life cycle, the development of the mammary gland is regulated by systemic hormones and local epithelial-mesenchymal interactions (Daniel \& Silberstein 1987, Sakakura 1987, Cunha 1994, Hennighausen \& Robinson 1998). In fact, the effects of hormones on mammary development are, at least in part, mediated by the modulation of these local paracrine interactions (McGrath 1983, Daniel \& Silberstein 1987, Hennighausen \& Robinson 1998). Although the 
importance of epithelial-mesenchymal interactions to mammary development has been appreciated for some time, the molecular mechanisms by which epithelial and mesenchymal cells communicate, and the ways in which systemic hormones affect their interactions, remain poorly understood.

One molecule that has recently been suggested to participate in epithelial-mesenchymal interactions is parathyroid hormone-related protein $(\mathrm{PTHrP})$. PTHrP was originally identified as the tumor product responsible for the clinical syndrome of humoral hypercalcemia of malignancy (Philbrick et al. 1996, Strewler 2000). It derives its name from the fact that its gene and the parathyroid hormone $(P T H)$ gene are both descended from a common ancestor. As a result, the two genes share sequence homology and structural characteristics that allow aminoterminal regions of $\mathrm{PTH}$ and $\mathrm{PTHrP}$ to signal through the same receptor, termed the type $1 \mathrm{PTH} / \mathrm{PTHrP}$ receptor (PTH-1R) (Philbrick et al. 1996, Strewler 2000). During development, PTHrP is produced by many epithelial structures, whereas the PTH-1R is often expressed on adjacent mesenchymal cells, suggesting a role for this ligand-receptor pair in epithelial-mesenchymal interactions (Lee et al. 1995, Wysolmerski \& Stewart 1998). The examination of mammary development in several mouse strains engineered to either overexpress or underexpress PTHrP, PTH-1R, or both, has confirmed that this is the case during mammary development (Wysolmerski et al. 1995, 1998, Dunbar et al. 1999, Foley et al. 2001).

We have previously documented that PTHrP signaling is necessary for embryonic mammary development. If either the PTHrP or the PTH-1R gene is disrupted in mice, mammary epithelial buds form, but never give rise to a duct system (Wysolmerski et al. 1998, Dunbar et al. 1999, Foley et al. 2001). Instead, the epithelial cells revert to an epidermal cell fate and, at birth, no mammary epithelial structures remain. During embryogenesis, the PTHrP gene is highly expressed in the epithelial cells of the mammary bud, and the PTH-1R gene is expressed in the surrounding mesenchymal cells (Wysolmerski et al. 1998). Consistent with these patterns of expression, recent experiments have shown that PTHrP acts as a signal from the epithelium that is necessary for the formation of a mammary-specific mesenchyme. In PTHrP or PTH1R knockout mice, no mammary mesenchyme forms (Dunbar et al. 1999, Foley et al. 2001). Alternatively, in transgenic mice that ectopically express PTHrP in the fetal epidermis, the entire ventral dermis is transformed into mammary mesenchyme (Wysolmerski et al. 1998, Foley et al. 2001). Therefore, it appears that PTHrP instructs the mesenchymal cells around the developing mammary bud to choose a mammary-specific fate and to direct subsequent mammary morphogenesis.

In addition to its actions during embryonic mammary development, PTHrP also may participate in the regulation of ductal branching morphogenesis during puberty. We have previously shown that overexpression of PTHrP in mammary epithelial cells, using the keratin 14 (K14) promoter, causes severe defects in ductal development during puberty and early pregnancy (Wysolmerski et al. 1995). Overexpression of PTHrP appears to have two main consequences, both of which become manifest only after the beginning of puberty. Firstly, the ducts grow through the mammary fat pad at a slower rate, and secondly, the main ducts give rise to many fewer secondary and tertiary branches. Furthermore, local delivery of PTHrP to the mammary gland slows the rate at which normal ducts grow (Wysolmerski et al. 1995). These results suggest that PTHrP might regulate the function of TEBs, a hypothesis consistent with localization studies showing that, during puberty, $\mathrm{PTHrP}$ is predominantly expressed by cap cells of end buds, whereas the PTH-1R is predominantly expressed on stromal cells surrounding the TEBs (Dunbar et al. 1998). However, given the profound influence of $\mathrm{PTHrP}$ on embryonic mammary development, we wondered if some aspects of the K14PTHrP phenotype might be secondary to the embryonic actions of PTHrP. In order to examine these questions, we used a tetracycline-regulated system to control the timing of PTHrP overexpression within the mammary gland. In the present study, we demonstrate that the K14-PTHrP mammary phenotype is the result of both embryonic and pubertal overexpression of PTHrP. Defects in the rate at which the epithelial ducts grow through the fat pad are due to the overexpression of PTHrP during puberty, whereas the defects in ductal branching during puberty appear to be a consequence of prior overexpression of PTHrP during embryogenesis.

\section{Materials and Methods}

\section{Transgenic mice}

The K14-tTA transgene was generated by inserting a $2 \cdot 1 \mathrm{~kb}$ portion of the human K14 promoter upstream of the tetracycline transactivator $(t T A)$ gene (Wysolmerski et al. 1994, Dunbar et al. 1998, Foley et al. 2001). The Tet $_{\mathrm{O}}-\mathrm{PTHrP}$ transgene was generated by inserting a $568 \mathrm{bp}$ human PTHrP(1-141) cDNA and $2 \cdot 2 \mathrm{~kb}$ of human growth hormone sequences downstream of a minimal CMV promoter containing seven concatamerized tetracycline-repressor binding sites. The growth hormone sequences provide RNA processing sites; they are transcribed but not translated (Wysolmerski et al. 1994, Dunbar et al. 1998, Foley et al. 2001). Transgenic mice were generated by pronuclear injection using standard techniques, and genotypes were analyzed by PCR (Foley et al. 2001). Tet ${ }_{\mathrm{O}}$-PTHrP mice were identified by amplification of a $171 \mathrm{bp}$ sequence of the human growth hormone gene using the following primers: forward, ctacgggctgctctactgcttcagg; reverse, ggcactggagtggcaacttc 
caagg (Dunbar et al. 1999). K14-tTA mice were identified by amplification of a $159 \mathrm{bp}$ sequence of the $t \mathrm{TA}$ gene using the following primers: forward, aacaaccegtaaactcgec; reverse, aaatcttgccagctttccc. Tet ${ }_{\mathrm{O}}-\beta$-gal mice were the gift of Dr Lothar Hennighausen, and were genotyped as described previously (Furth et al. 1994). K14-tTA/Tet ${ }_{\mathrm{O}^{-}}$ $\mathrm{PTHrP}$ double transgenic mice were created by crossing K14-tTA transgenic mice with Tet $_{\mathrm{O}}-\mathrm{PTHrP}$ transgenic mice. Tet $_{\mathrm{O}}-\mathrm{PTHrP}$ transgene expression was suppressed by feeding double transgenic mice $150 \mu \mathrm{g} / \mathrm{ml}$ tetracycline hydrochloride (Roche, Indianapolis, IN, USA) in 5\% sucrose water. All animal experimentation was conducted in accord with accepted standards of humane animal care.

\section{$\beta$-Galactosidase assay}

$\beta$-Galactosidase activity was measured in embryonic and adult mammary tissue according to the procedure described by Furth et al. (1994). For adult tissue, the no. 4 inguinal mammary glands of mice were dissected and scored every $5 \mathrm{~mm}$, to allow penetration of the fixative and reaction mixture. For embryonic tissue, whole embryos were harvested and fixed, and ventral skin was dissected after fixation. The tissue was fixed in $2 \%$ paraformaldehyde and $0.02 \%$ glutaraldehyde in phosphate buffered saline (PBS) for $1 \mathrm{~h}$ at room temperature and then washed twice in PBS. To assay for $\beta$-galactosidase, the tissue was incubated in a buffered solution containing $0 \cdot 1 \%$ 4-chloro-5-bromo-3 indolyl $\beta$-D-galactopyranoside, $2 \mathrm{mM} \mathrm{MgCl} 2,5 \mathrm{mM}$ EGTA, $0 \cdot 02 \%$ Nonidet P-40, $5 \mathrm{mM}$ $\mathrm{K}_{3} \mathrm{Fe}(\mathrm{CN})_{6}$ and $5 \mathrm{mM} \mathrm{K}{ }_{4} \mathrm{Fe}(\mathrm{CN})_{6} \cdot 6 \mathrm{H}_{2} \mathrm{O}$ at $30{ }^{\circ} \mathrm{C}$ for at least $1 \mathrm{~h}$ and up to $24 \mathrm{~h}$, depending on the color reaction. After staining, the tissue was post-fixed in 4\% paraformaldehyde overnight at $4{ }^{\circ} \mathrm{C}$ and embedded in paraffin. Sections $5 \mu \mathrm{m}$ thick were cut and counterstained with eosin.

\section{$R N A$ isolation and RNase protection analysis}

Total RNA was isolated from mammary tissue using Trizol reagent (Gibco, Gaithersville, MD, USA). RNase protection analysis was performed as described previously (Daifotis et al. 1992) using $2 \times 10^{5}$ c.p.m. of labeled antisense cRNA probes corresponding to a 153-bp Bgl II-Pvu II fragment of the human growth hormone gene and a 220-bp Sau3a-Sau3a fragment of the mouse cyclophilin gene.

\section{Whole-mount analysis}

Whole-mount analysis was performed on mammary tissue as previously described (Wysolmerski et al. 1995). Briefly, the no. 4 inguinal mammary glands were removed and mounted on a microscope slide. The tissue was fixed in acid ethanol for $1 \mathrm{~h}$ at room temperature, washed in $70 \%$ ethanol and distilled water and incubated in carmine aluminum stain $(0 \cdot 2 \%$ carmine, $0 \cdot 5 \%$ aluminum potassium sulfate) for $10-12 \mathrm{~h}$ at room temperature. After staining, the mammary glands were dehydrated through graded ethanol and defatted in acetone $(6-8 \mathrm{~h})$ and toluene (15 min) before being mounted under glass coverslips using Permount (Fisher Scientific, Fair Lawn, NJ, USA). For light microscopy, mammary tissue was fixed in $4 \%$ paraformaldehyde for $10-12 \mathrm{~h}$ at $4{ }^{\circ} \mathrm{C}$, embedded in paraffin and sectioned at $5 \mu \mathrm{m}$ for hematoxylin \& eosin (H\&E) staining. Histomorphometry was performed on whole mounts and the following parameters were measured: total duct length was measured from the nipple region to the leading edge of the most distal endbud; the percentage of fat pad penetration was calculated by dividing the total duct length by the distance from the nipple region to the most distal aspect of the fatty stroma; branches per $5 \mathrm{~mm}^{2}$ records the average total number of branch points occurring within 15 random sample areas each $5 \mathrm{~mm}^{2}$ in size; the number of branches off primary duct records the absolute number of branches arising from the entire length of the three or four main ducts.

\section{Cell proliferation and cell death assays}

Five-week-old mice were injected with $100 \mu \mathrm{Ci}\left[{ }^{3} \mathrm{H}\right]$ thymidine (Amersham, Piscataway, NJ, USA) 45 min before tha animal was killed. Hormone-treated mice were injected (i.p.) with an aqueous solution of estradiol $(24 \mu \mathrm{g} /$ day) and progesterone $(1.2 \mathrm{mg} /$ day $)$ for 2 days before injection of $\left[{ }^{3} \mathrm{H}\right]$ thymidine (Wysolmerski et al. 1995). The mice were killed and the no. 4 inguinal mammary glands were harvested, fixed in 4\% paraformaldehyde overnight, washed in $70 \%$ ethanol, embedded in paraffin and sectioned at $5 \mu \mathrm{m}$. The sections were then deparaffinized, rehydrated through graded ethanol to distilled water and post-fixed in $10 \%$ buffered formalin for $5 \mathrm{~min}$ at room temperature. After this, sections were counterstained with hematoxylin, dehydrated through graded ethanol, dipped in photographic emulsion (NTB-2, Kodak), air dried and stored at $4{ }^{\circ} \mathrm{C}$ for $7-10$ days in the dark with desiccant. After being developed, the sections were again dehydrated through graded ethanol and coverslipped.

Cell death assays were performed by terminal deoxynucleotidyl transferase-mediated dUTP nick end labelling (TUNEL) analysis using the In Situ Cell Death kit from Boehringer-Mannheim (Roche). Briefly, sections of mammary tissue were incubated with proteinase $\mathrm{K}$ at a concentration of $20 \mu \mathrm{g} / \mathrm{ml}$ in $10 \mathrm{mM}$ Tris $\mathrm{HCl}$ for $5 \mathrm{~min}$ at $37^{\circ} \mathrm{C}$. They were then washed in $1 \times \mathrm{PBS}$ and incubated with the terminal deoxytransferase reaction mixture at $37^{\circ} \mathrm{C}$ for $45 \mathrm{~min}$ in the dark. After TUNEL labeling, the sections were washed with $1 \times$ PBS and mounted for fluorescent microscopy using the Prolong Antifade reagent (Molecular Probes).

Apoptosis and cell proliferation were quantitated using photomicrographs of TEBs from TUNEL and $\left[{ }^{3} \mathrm{H}\right]$ thymidine experiments. Fifteen TEBs from a total of five mice 


\section{K14 - tTA}
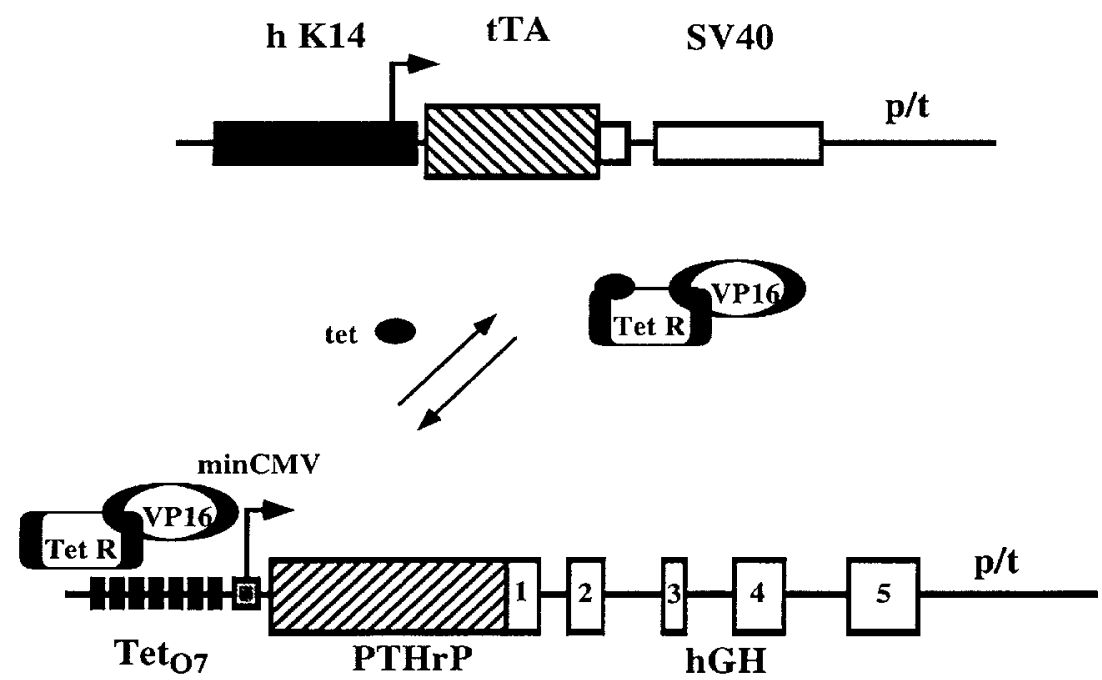

\section{Tet $_{\text {O }}$ - PTHrP}

Figure 1 Regulated K14-PTHrP transgenic mouse. The K14-tTA transgene consisted of the human (h) K14 promoter driving expression of the (tet) tetracycline transactivator (tTA) cDNA, which encodes a fusion protein consisting of the DNA binding domain of the tetracycline repressor protein (Tet R) and the transciptional activation domain of VP16. SV40 sequences are included for RNA processing. The $\mathrm{Tet}_{\mathrm{O}}-\mathrm{PTHrP}$ transgene consists of the human PTHrP(1-141) cDNA under the control of a minimal CMV (minCMV) promoter with seven tetracycline operon binding sites $\left(\right.$ tet $\left._{\mathrm{O} 7}\right)$ and human growth hormone $(\mathrm{hGH})$ gene sequences provided for RNA processing. These GH sequences are transcribed but not translated. In double transgenic mice, the tTA protein is produced in tissues expressing K14. This is a 'tet-off' system: if tetracycline is absent, the tTA protein binds to and activates transcription of the Tet $_{\mathrm{O}}-\mathrm{PTHrP}$ transgene; however, if tetracycline is present, the tTA protein is prevented from binding and the Tet $_{\mathrm{O}}-\mathrm{PTHrP}$ transgene remains silent. $\mathrm{p} / \mathrm{t}$, polyadenylation/termination sequences.

(three per mouse) were counted for each experimental condition. For TUNEL analysis, clusters of positively labeled nuclei occurring within a single cell diameter were considered to be fragments of a central cell and were counted as a single apoptotic cell. For cell proliferation experiments, cells demonstrating four or more silver grains located over nuclei were counted as positive (Zeps et al. 1996).

Figure 2 (A-F) Mammary tissues harvested from $\mathrm{K} 14-\mathrm{tTA} / \mathrm{Tet}_{\mathrm{O}}-\beta$-gal double transgenic mice and stained for $\beta$-galactosidase activity: $\mathrm{A}$, $\mathrm{B}$, $\mathrm{D}-\mathrm{F}$ were raised off tetracycline and $\mathrm{C}$ was raised on tetracycline. (A) Section $(5 \mu \mathrm{m})$ through a mammary bud from an embryo at embryonic day 15. (B) Similar section taken from an adult virgin mammary gland. (C) Section ( $5 \mu \mathrm{m})$ through a duct from an adult mammary gland from a mouse raised on tetracycline. (D) Terminal end bud from a whole-mount preparation of a 5-week-old mammary gland. (E) Section $(5 \mu \mathrm{m})$ through a terminal end bud from a 5-week-old mouse. 9F) Section $(5 \mu \mathrm{m})$ through developing lobuloalveolar units from a 12-day pregnant gland. Note that $\beta$-galactosidase activity is present in all the epithelial cells of the embryonic gland (A), but only in the myoepithelial cells of the mature virgin duct (B) and the developing lobuloalveoli (F). $\beta$-Galactosidase is also present in the cap cells at the leading edge of the terminal end buds ( $D$, and arrows in $E$ ) and the differentiating myoepithelial cells at the neck region. In the presence of tetracycline, no $\beta$-galactosidase activity was detected (C). (G) RNase protection assay on RNA prepared from mammary glands harvested from mature virgin $\mathrm{K} 14-\mathrm{tTA} / \mathrm{Tet}_{\mathrm{O}}-\mathrm{PTHrP}$ mice raised either on tetracycline or off tetracycline. Note that, in the presence of tetracycline, the $\mathrm{Tet}_{\mathrm{O}}-\mathrm{PTHrP}$ transgene is not expressed, whereas in the absence of tetracycline, transgene-derived mRNA is easily detected. 
A.

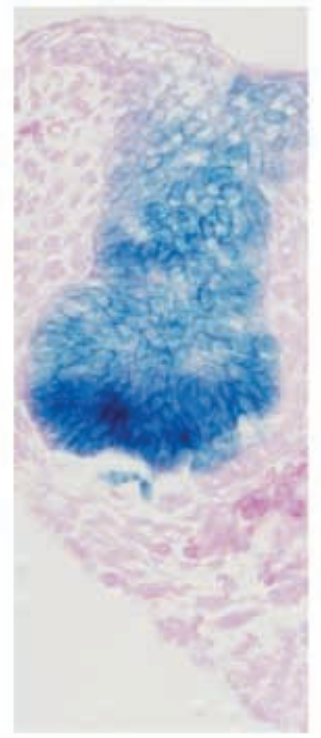

D.

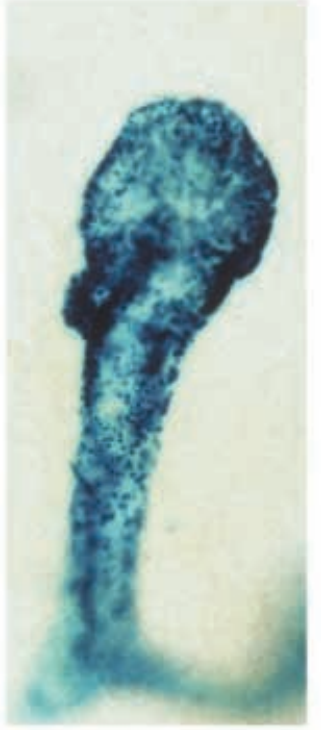

B.
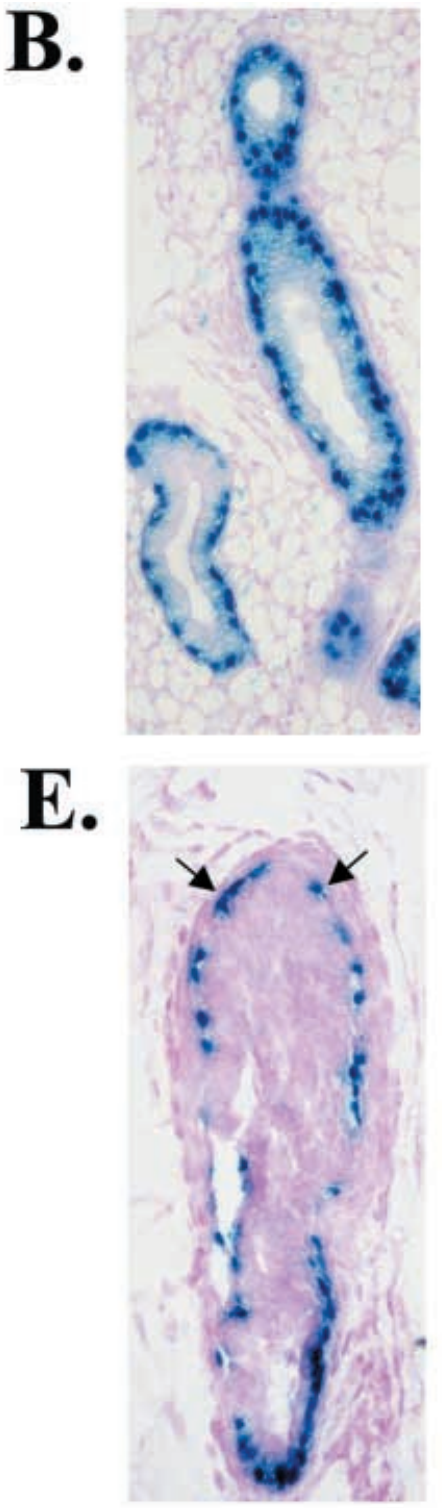

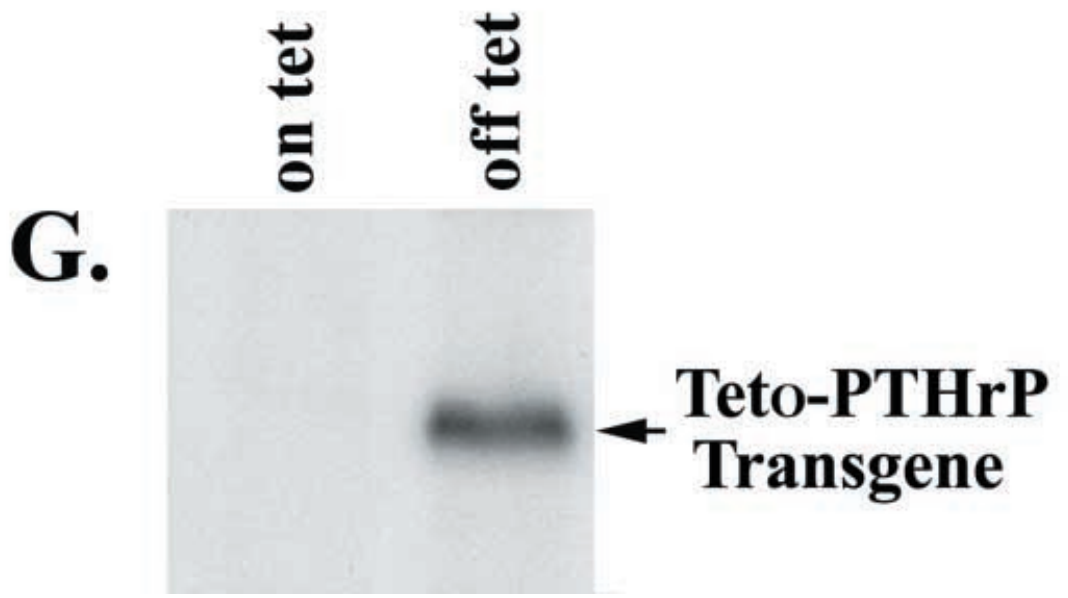

C.

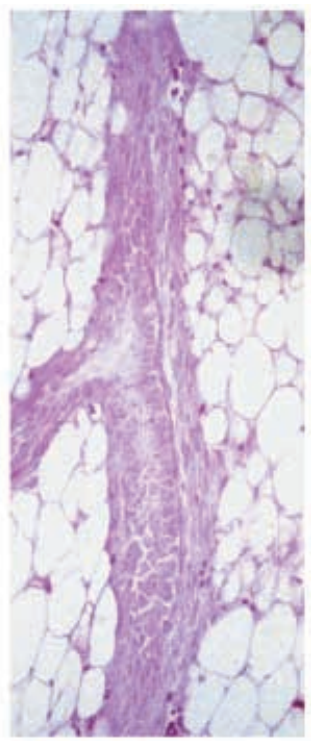

F.

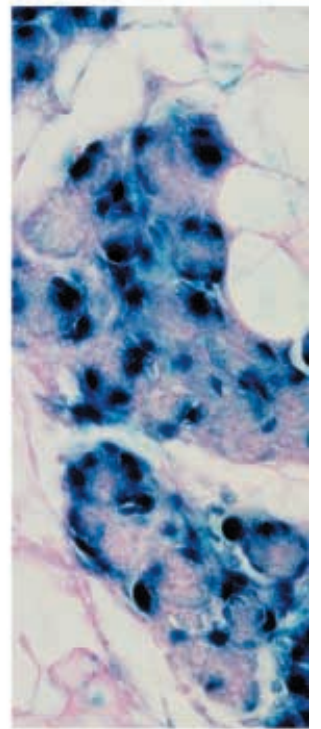




\section{Results}

Generation and validation of K14-tTA/Tet ${ }_{O}-\mathrm{PTHrP}$ double transgenic mice

In order to determine if the pubertal defects caused by overexpression of PTHrP were due to effects of PTHrP during mammary embryogenesis, we created a binary K14-PTHrP transgenic mouse that enabled us to regulate PTHrP production in a temporal fashion. As shown in Fig. 1, we made two transgenic mouse lines, one bearing a K14-tTA transgene and the other bearing a Tet $_{\mathrm{O}^{-}}$ PTHrP transgene. Neither of these individual transgenic strains had defects in mammary ductal development, demonstrating that the tTA protein was not toxic to mammary epithelial or myoepithelial cells (data not shown). We next bred these two transgenic strains together to generate double transgenic (K14-tTA/ $\mathrm{Tet}_{\mathrm{O}^{-}}$ PTHrP) mice. As we utilized a 'tet-off' system, double transgenic mice fed tetracycline should not produce excess PTHrP, but withdrawal of tetracycline should allow for PTHrP overexpression.

In order to test the ability of the K14-tTA transgene to activate target transgene expression correctly in this fashion, we first bred the K14-tTA line to a Tet ${ }_{\mathrm{O}}-\mathrm{lacZ}$ reporter mouse (Furth et al. 1994). The resulting double transgenic (K14-tTA/Tet ${ }_{\mathrm{O}}-\mathrm{lacZ}$ ) mice would be expected to express $\beta$-galactosidase in a K14-dependent manner, only when tetracycline is absent. Figure 2 shows $\beta$-galactosidase staining of mammary glands from K14tTA/Tet $\mathrm{O}_{-}$lacZ embryos and adult females. As one can see, the epithelial cells of the embryonic mammary bud, in addition to those in the adult virgin mammary gland, appeared to be completely normal, again demonstrating that the presence of tTA within these cells was not toxic. As expected, when these mice were raised off tetracycline, $\beta$-galactosidase activity (as indicated by the blue color) was present in all the epithelial cells of the embryonic mammary bud and in the myoepithelial cells of the adult virgin mammary gland (Fig. 2A, B). In contrast, no $\beta$-galactosidase activity was observed in the mammary glands of double transgenic mice raised on tetracycline (Fig. 2C), demonstrating that the $\mathrm{Tet}_{\mathrm{O}}-\mathrm{lac} \mathrm{Z}$ transgene is fully repressed in the presence of tetracycline. $\beta$-galactosidase activity was also detected in TEBs (Fig. $2 \mathrm{D}, \mathrm{E})$, both in the cap cells at the leading edge and the differentiating myoepithelial cells at the sides and neck, and in myoepithelial cells within the developing lobuloalveolar units during pregnancy (Fig. 2F). All of these sites have been previously shown to express K14 (Taylor-Papdimitriou \& Lane 1987, Smith et al. 1990, Wysolmerski et al. 1995, 1998). Similar results were seen when the skin of the $\mathrm{K} 14-\mathrm{tTA} / \mathrm{Tet}_{\mathrm{O}}-\mathrm{lacZ}$ mice was analyzed for $\beta$-galactosidase activity (Foley et al. 2001). These results demonstrate that the K14-tTA transgene activates target transgene expression in a tetracyclinedependent manner only at sites of K14 expression. In the mammary gland, these include the epithelial cells of the embryonic mammary bud, the myoepithelial cells of the postnatal gland, and the cap cells of the TEB during puberty.

We next investigated whether tetracycline administration could effectively regulate PTHrP transgene expression in the mammary glands of K14-tTA/ $\mathrm{Tet}_{\mathrm{O}}-\mathrm{PTHrP}$ double transgenic mice. Expression of the Tet $_{\mathrm{O}}-\mathrm{PTHrP}$ transgene was assayed in total cellular RNA prepared from whole mammary glands of double transgenic mice on or off tetracycline. As can be seen in Fig. 2E, K14-tTA/ Tet $_{\mathrm{O}}-\mathrm{PTHrP}$ mice raised off tetracycline expressed the Tet $_{\mathrm{O}}-\mathrm{PTHrP}$ transgene, but double transgenic mice raised on tetracycline did not. Furthermore, the levels of transgene expression in the K14-tTA/ $\mathrm{Tet}_{\mathrm{O}}$-PTHrP mice raised off tetracycline were similar to those seen in the original K14-PTHrP mice (data not shown). Therefore, the binary K14-PTHrP system provides an effective 'on-off' switch to the original K14PTHrP transgene and allows for temporal regulation of PTHrP overexpression in the mammary gland.

\section{K14-tTA/Tet $-P T H r P$ double transgenic mice recapitulate} the mammary phenotype of the K14-PTHrP single transgenic mice

The mammary phenotype of K14-PTHrP transgenic mice consists of impaired ductal elongation and ductal branching during puberty. In order to determine if we could recapitulate these changes using our tetracycline-regulated system, we analyzed mammary development in 7-weekold K14-tTA/ Tet $_{\mathrm{O}}-\mathrm{PTHrP}$ female mice, raised either on tetracycline (never exposed to PTHrP overexpression) or off tetracycline (always exposed to PTHrP overexpression). As shown by whole-mount analysis in Fig. 3A, mammary glands from $\mathrm{K} 14-\mathrm{tTA} / \mathrm{Tet}_{\mathrm{O}}-\mathrm{PTHrP}$ mice raised on tetracycline appeared to be completely normal. At this stage of development, the epithelial duct system had consistently reached the borders of the mammary fat pad, and it displayed a highly organized and complex branched architecture. In contrast, in double transgenic mice raised off tetracycline, both aspects of the K14PTHrP phenotype were reproduced. As seen in Fig. 3B, the overall penetration of the duct system into the fat pad was reduced, and there was a reduction in the degree of branching. Therefore, the K14-tTA/ Tet $_{\mathrm{O}}-\mathrm{PTHrP}$ double transgenic mice reproduce the full spectrum of abnormalities caused by PTHrP overexpression, and these defects are completely prevented by feeding the mice tetracycline.

\section{Abnormalities of ductal elongation are caused by postnatal overexpression of PTHrP and abnormalities in ductal branching are caused by prenatal overexpression of PTHrP}

Although K14-driven transgene expression begins in the mammary bud as early as embryonic day 15 (Dunbar et al. 


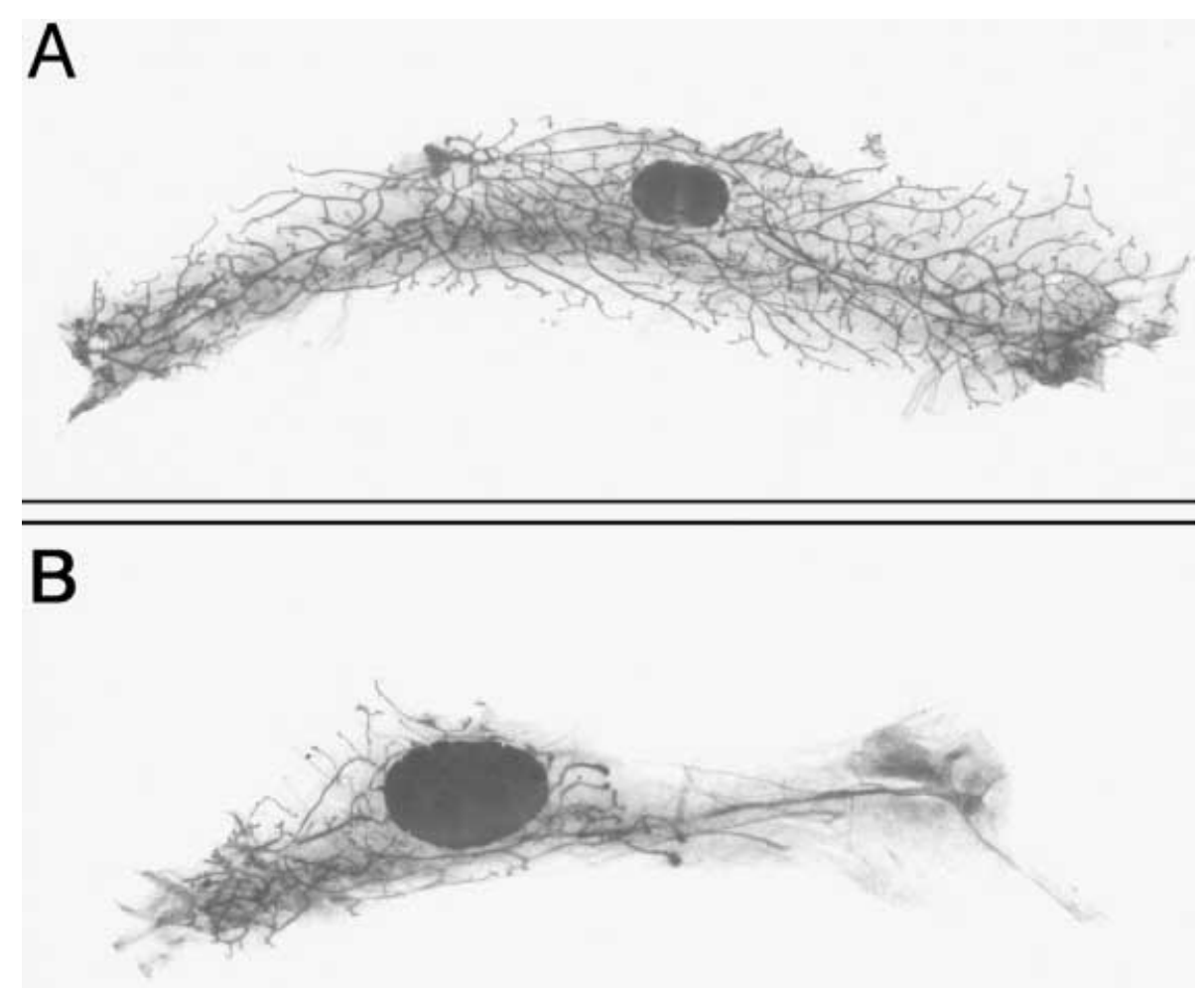

Figure 3 Whole-mount analysis of mammary glands harvested from 7-week-old K14-tTA/Tet $\mathrm{O}^{-}$ PTHrP mice raised either on tetracycline (A) or off tetracycline (B). In the presence of tetracycline, mammary ducts develop normally $(\mathrm{A})$; in the absence of tetracycline, there are defects in ductal extension and branching (B).

1999), mammary abnormalities in the K14-PTHrP mice were not evident until the onset of puberty. Therefore, our working hypothesis was that overexpression of $\mathrm{PTHrP}$ during puberty would be responsible for the abnormal ductal proliferation and branching that occurred during this period. However, because PTHrP deficiency causes profound defects in embryonic mammary development, we examined the possibility that some of the effects of $\mathrm{PTHrP}$ overexpression might also be the result of PTHrP acting on the embryonic gland. In order to address this question, we utilized our tetracycline-regulated system to alter the timing of transgenic PTHrP production. K14tTA/ Tet $_{\mathrm{O}}$-PTHrP double transgenic mice were exposed to tetracycline either from conception until birth, or from birth until they were killed, to provide for postnatal or prenatal overexpression of PTHrP respectively. Mammary gland development was analyzed towards the end of puberty, at 7 weeks of age. As shown in Fig. 4A, at this stage of development the duct system in normal mice has reached the borders of the mammary fat pad and has a highly branched organization. As compared with wildtype mice, when double transgenic mice were exposed to PTHrP overexpression only after birth, the overall growth of the epithelial ducts through the mammary fat pad was significantly impaired and the tips of the growing ducts had not reached the distal end of the fat pad (Fig. 4B). However, as compared with either the original K14PTHrP mice or the double transgenic mice never exposed to tetracycline, these mice exhibited minimal defects in the branching pattern of the epithelial ducts. Similar results were obtained when the mice were taken off tetracycline at the beginning of puberty ( 3 weeks of age, data not shown). In contrast, when double transgenic mice were exposed to PTHrP overexpression only before birth, the opposite pattern emerged: the glands from these mice demonstrated a severe reduction in branching complexity but only a minor reduction in the rate of ductal elongation (Fig. 4C).

In order to quantify the defects noted above, we performed histomorphometry in glands harvested from 10 double transgenic mice (five exposed to postnatal overexpression of PTHrP and five exposed to prenatal overexpression). The results are shown in Table 1. Ductal elongation, as assessed either by the total length of the duct system or by the percentage of the fat pad penetrated by ducts, was significantly reduced in mice exposed to postnatal, but not prenatal, transgene expression. Branching complexity, as determined by measuring the average 


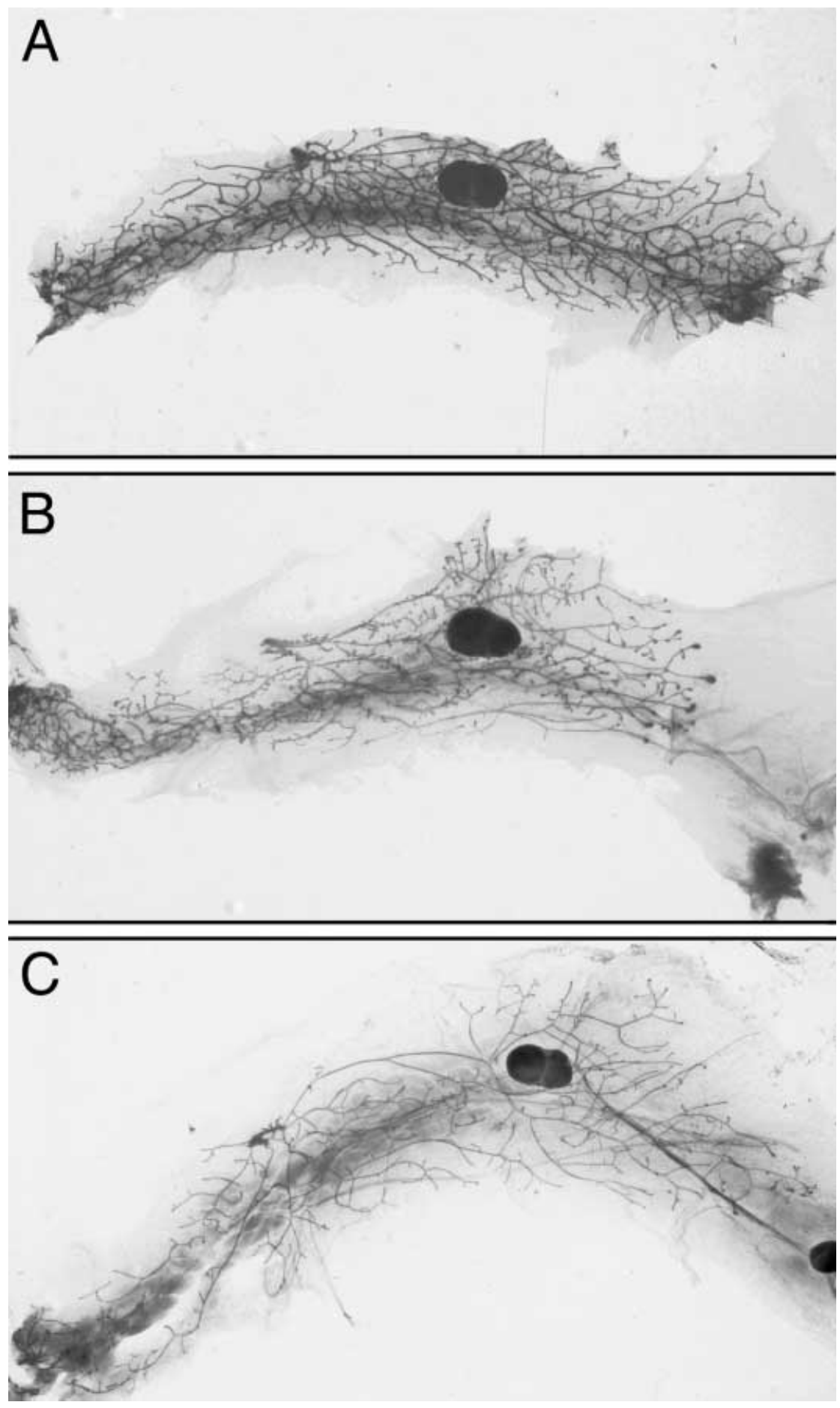

Figure 4 Whole-mount analysis of mammary glands harvested from a wild-type mouse (A), or from K14-tTA/Tet ${ }_{\mathrm{O}}$-PTHrP double transgenic mice exposed to PTHrP overexpression only after birth (B) or only before birth (C). All mice were killed at 7 weeks of age. Note that when PTHrP was expressed only after birth, there were significant defects in ductal extension, but only very mild defects in branching (B); however, when PTHrP was overexpressed only before birth, there was a significant reduction in ductal branching, but only slight impairments in duct extension. $\mathrm{K} 14-\mathrm{tTA} / \mathrm{Tet}_{\mathrm{O}}-\mathrm{PTHrP}$ control mice that were always receiving tetracycline were also analyzed and were identical to wild-type mice. 
Table 1 Histomorphometry of double transgenic (Dbl Tg) mammary glands: each measurement was performed on five separate glands, and node analysis was performed on 15 sample areas, each $5 \mathrm{~mm}^{2}$ in size

\begin{tabular}{|c|c|c|c|c|}
\hline & $\begin{array}{l}\text { Total duct length } \\
(\mathrm{cm})\end{array}$ & $\begin{array}{l}\text { Fat pad } \\
\text { penetration }(\%)\end{array}$ & $\begin{array}{l}\text { Branches per } \\
5 \mathrm{~mm}^{2} \text { (No.) }\end{array}$ & $\begin{array}{l}\text { Branches off } \\
\text { primary duct (No.) }\end{array}$ \\
\hline Wild-type & $1 \cdot 5 \pm 0 \cdot 1$ & $91 \pm 3$ & $66 \pm 6$ & $19 \pm 2$ \\
\hline \multicolumn{5}{|l|}{$\mathrm{Dbl} \mathrm{Tg}$} \\
\hline PTHrP overexpression after birth & $0 \cdot 9 \pm 0 \cdot 1^{*}$ & $59 \pm 5^{*}$ & $52 \pm 3$ & $18 \pm 1$ \\
\hline PTHrP overexpression before birth & $1 \cdot 3 \pm 0 \cdot 1$ & $81 \pm 5$ & $24 \pm 2^{*}$ & $13 \pm 1^{*}$ \\
\hline
\end{tabular}

Data are represented as the means \pm S.E.M. ${ }^{*} P<0.05$ compared with wild-type (Student's t-test).
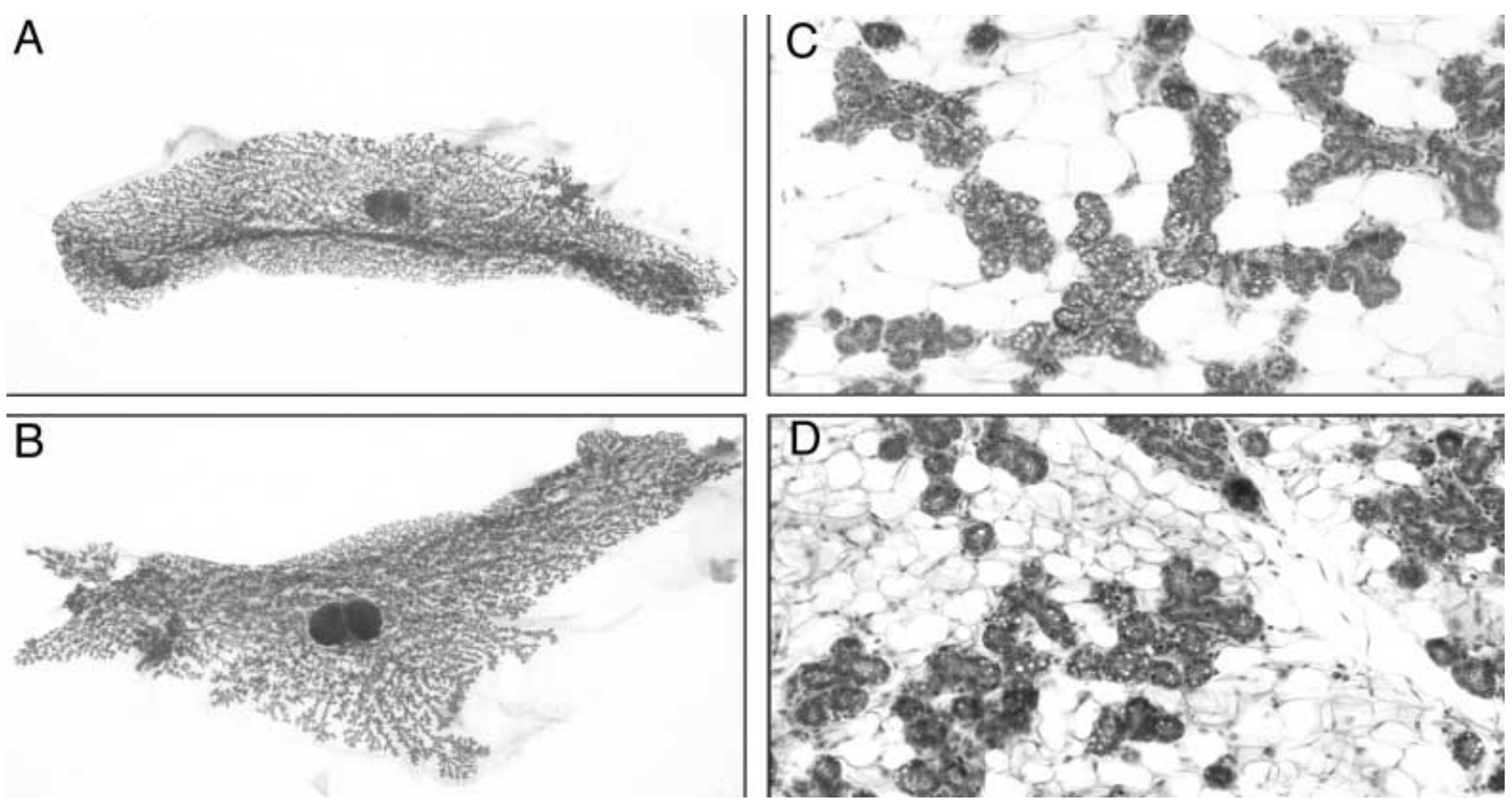

Figure 5 Lobuloalveolar development in $\mathrm{K} 14-\mathrm{tTA} / \mathrm{Tet}_{\mathrm{O}}$-PTHrP double transgenic mice exposed to PTHrP overexpression after ductal development was completed. (A,C) Taken from wild-type mice at day 15 of pregnancy. (B,D) From double transgenic mice that were raised on tetracycline until 8 weeks of age and then were allowed to become pregnant 2 weeks later. These mice were also killed on day 15 of pregnancy. (A,B) Whole mounts. (C,D) Sections $(5 \mu \mathrm{m})$ stained with H\&E. Note that if PTHrP overexpression is delayed until after duct development is completed, there is no defect in lobuloalveolar development.

number of branch points per $5 \mathrm{~mm}^{2}$ area or by counting the number of branches arising from each primary duct, was significantly reduced in double transgenic mice exposed to prenatal, but not postnatal, PTHrP overexpression. Taken together, these results suggest that the impairment in ductal elongation in the $\mathrm{K} 14-\mathrm{PTHrP}$ mice is due to the effects of PTHrP during puberty, but that the defects in ductal branching are due to the effects of PTHrP during embryonic development.

\section{Overexpression of PTHrP during pregnancy does not affect lobuloalveolar development}

In addition to alterations in ductal development during puberty, K14-PTHrP mice also demonstrate a delay in the formation of lobuloalveolar structures, and a reduction in the total lobuloalveolar mass formed during pregnancy. Our initial characterization of this defect had suggested that it was partly a consequence of the inability to form terminal ductules during the early stages of pregnancy. However, it was unclear if overexpression of PTHrP might also directly impair lobuloalveolar differentiation. To address this question, we used the tetracyclineregulated system to overexpress PTHrP only during pregnancy. In order to allow for normal ductal development, K14-tTA/ Tet $_{\mathrm{O}}-\mathrm{PTHrP}$ double transgenic mice were raised on tetracycline until the end of puberty, when the adult branching pattern had been fully established. At that point, tetracycline was withdrawn and transgene expression was initiated. After 2 weeks, the mice were allowed to 
become pregnant and lobuloalveolar development was examined at 15 days of gestation. As shown in Fig. 5, if PTHrP was overexpressed only after the completion of ductal development, there appeared to be no effect on mammary development during pregnancy (Fig. 5B,D). The glands from these mice demonstrated robust lobuloalveolar development and were indistinguishable from those of controls (Fig. 5A,C). These data suggest that overexpression of PTHrP in myoepithelial cells has no direct effect on lobuloalveolar differentiation and that the defects in pregnant K14-PTHrP mice are a consequence of the pre-existing abnormalities of ductal morphogenesis.

Impairment of ductal elongation during puberty is associated with alterations in cell turnover within terminal end buds

At the onset of puberty, the distal ends of the mammary ducts form specialized structures called terminal end buds (TEBs), which serve as sites of active cellular turnover and differentiation. Various studies have shown that the TEBs are the main locus of epithelial proliferation and apoptosis during puberty (Daniel \& Silberstein 1987), and presumably the balance between these processes determines the rate at which the ducts grow through the mammary fat pad. We have previously shown that TEBs and their surrounding stroma are also the major site of $P T H r P$ and PTH-1R gene expression during puberty (Dunbar et al. 1998), therefore we hypothesized that overexpression of PTHrP during puberty might impair ductal elongation by altering epithelial cell proliferation, epithelial cell death, or both, within the TEBs. In order to approach this question, we examined rates of cellular proliferation and apoptosis within the TEBs of K14-PTHrP transgenics and compared them with those in wild-type mice. Similarly, we studied $\mathrm{K} 14-\mathrm{tTA} / \mathrm{Tet}_{\mathrm{O}}$-PTHrP double transgenic mice in which transgene expression was activated at birth, as they display defects in ductal elongation in the absence of significant branching defects. We studied mice during early puberty (4-5 weeks of age) at baseline and after $48 \mathrm{~h}$ of treatment with exogenous estrogen and progesterone.

We assessed TEB proliferation by measuring $\left[{ }^{3} \mathrm{H}\right]$ thymidine incorporation (Fig. 6A). At baseline, $14 \pm 1.5 \%$ of epithelial cells in wild-type end buds incorporated thymidine. After hormone treatment, significantly more of the epithelial cells $(23 \pm 0 \cdot 83 \%)$ within TEBs were labeled. Overexpression of PTHrP did not appear to affect baseline proliferation within the TEBs, as there were no differences in thymidine incorporation between wild-type mice $(14 \pm 1 \cdot 5 \%)$ and $\mathrm{K} 14-\mathrm{PTHrP}$ transgenics $(14 \pm 1 \cdot 1 \%)$ or K14-tTA/ Tet $_{\mathrm{O}}$-PTHrP double transgenics that were exposed to PTHrP overexpression after birth $(13 \cdot 8 \pm 2 \cdot 1 \%)$. However, overexpression of $\mathrm{PTHrP}$ did prevent the increase in proliferation that normally occurs in response to hormone treatment, as rates of proliferation after estrogen and progesterone treatment did not increase either in the
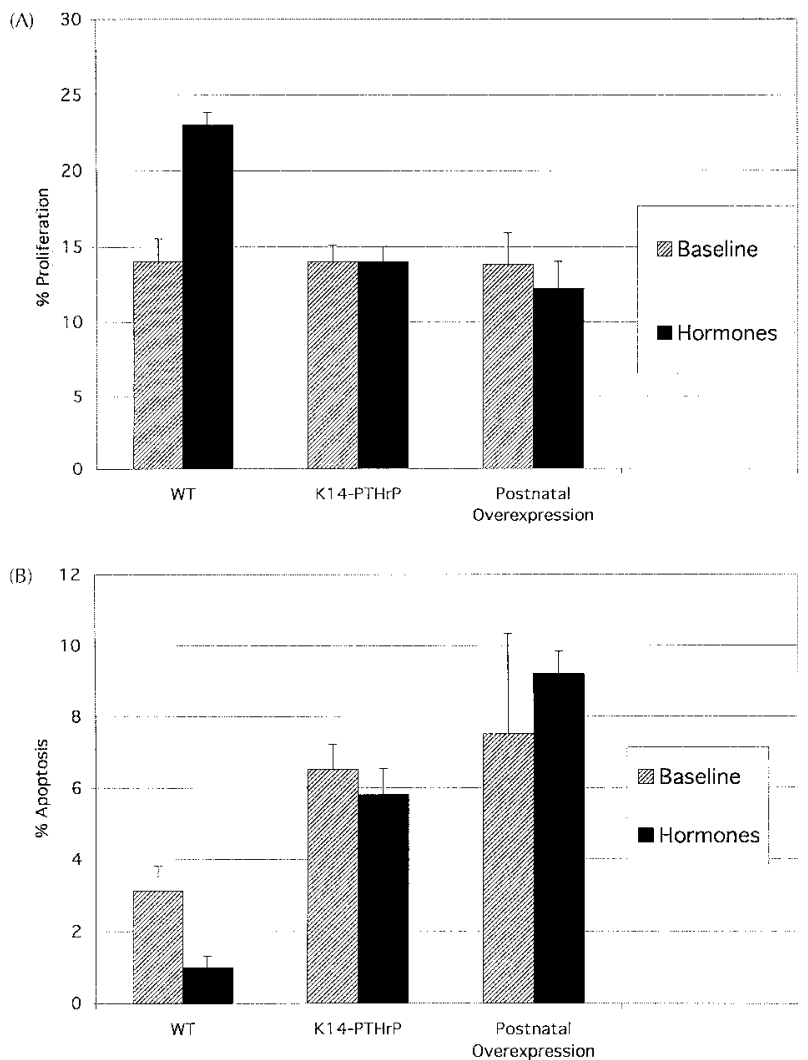

Figure 6 Effects of PTHrP overexpression on cell turnover in terminal end buds during puberty. (A) End bud cell proliferation in 5 -week-old mice as determined by $\left[{ }^{3} \mathrm{H}\right]$ thymidine incorporation, showing the percentage of epithelial cells incorporating thymidine within end-buds of wild-type (WT), standard K14-PTHrP transgenics and $\mathrm{K} 14-\mathrm{tTA} / \mathrm{Tet}_{\mathrm{O}}-\mathrm{PTHrP}$ double transgenic mice exposed to PTHrP overexpression only after birth (postnatal overexpression). Baseline: data for 5-week-old mice; Hormones: data for 5-week-old mice treated with exogenous estradiol and progesterone for $48 \mathrm{~h}$ before being injected with $\left[{ }^{3} \mathrm{H}\right]$ thymidine. Thymidine incorporation was statistically significantly greater in wild-type mice treated with hormones than in wild-type mice at baseline. Incorporation was statistically significantly lower in both transgenic groups treated with hormones than in the

hormone-treated wild-type mice. (B) End bud cell apoptosis in 5 -week-old mice as determined by TUNEL assay, showing the percentage of epithelial cells undergoing apoptosis within end buds of wild-type (WT), standard K14-PTHrP transgenics and K14-tTA/Tet ${ }_{\mathrm{O}}$-PTHrP double transgenic mice exposed to PTHrP overexpression only after birth (postnatal overexpression). Baseline: data for 5-week-old mice; Hormones: data for 5-week-old mice treated with exogenous estradiol and progesterone for $48 \mathrm{~h}$ before being injected with $\left[{ }^{3} \mathrm{H}\right]$ thymidine. At baseline, there was a statistically significantly greater percentage of cells undergoing apoptosis in the transgenic groups as opposed to the wild-type mice. In hormone-treated wild-type mice, there was a statistically significant decline in the percentage of apoptotic cells, but in either group of transgenic mice, hormone-treatment had no effect on cell death rates. All data are represented as the mean \pm S.E.M. Statistical significance was assessed by Student's $t$-test, and significance was set as a $P$ value of $<0 \cdot 05$. 
K14-PTHrP TEBs $(14 \pm 1 \cdot 0 \%)$ or in the K14-tTA/ Tet $_{\mathrm{O}^{-}}$ PTHrP double transgenic TEBs $(12 \cdot 2 \pm 1 \cdot 8 \%)$.

We assessed TEB apoptosis by TUNEL assay (Fig. 6B). In wild-type mice, an average of $3 \cdot 1 \pm 0 \cdot 7 \%$ of epithelial cells within TEBs were undergoing apoptosis at baseline, and this number decreased to $0.98 \pm 0.3 \%$ of the cells upon hormone treatment. In contrast to the results regarding cell proliferation, overexpression of PTHrP did affect baseline rates of cell death within the TEBs. Rates of TEB apoptosis were significantly greater both in K14-PTHrP transgenic mice $(6.5 \pm 0.7 \%)$ and in $\mathrm{K} 14-\mathrm{tTA} / \mathrm{Tet}_{\mathrm{O}^{-}}$ $\mathrm{PTHrP}$ double transgenic mice that had been exposed to PTHrP overexpression only after birth $(7 \cdot 5 \pm 2 \cdot 8 \%)$. In addition, in the transgenic mice, there was no reduction of apoptosis in response to hormone treatment. As has been previously documented, apoptosis occurred within the body cells of TEBs, both in wild-type and transgenic mice.

In summary, the defects in ductal elongation caused by the overexpression of PTHrP during puberty are associated with greater basal rates of epithelial cell apoptosis in TEBs, coupled with a failure to increase cell proliferation and reduce apoptosis in response to systemic estrogen and progesterone. Furthermore, these changes do not appear to be a result of prior morphological changes in the duct system, for they also occur in K14-tTA/ Tet $_{\mathrm{O}}-\mathrm{PTHrP}$ double transgenic mice that have been exposed to transgene expression only after birth.

\section{Discussion}

Previous work from our laboratory has shown that overexpression of PTHrP in mice impaired mammary duct elongation and branching during puberty (Wysolmerski et al. 1995). In this study we have demonstrated that the effects of PTHrP on pubertal mammary development depend on the timing of its overexpression. Using a tetracycline-regulated K14 transgene, we either transiently overexpressed PTHrP during embryonic mammary development or delayed overexpression of PTHrP until embryogenesis was complete. If PTHrP was overexpressed only before birth, the ductal branching pattern was altered during puberty, but the rate of elongation was largely unaffected. Conversely, if PTHrP was overexpressed after birth or at the commencement of puberty, ductal elongation was impaired, but branching was not. Furthermore, our results suggest that overexpression of PTHrP during puberty impairs ductal elongation by increasing the basal rate of epithelial cell apoptosis in terminal end buds and by preventing the normal changes in end bud cell turnover that occur in response to estrogen and progesterone.

Our data document that the 'tet-off' tetracyclineregulated transgenic system works well in the mammary gland. Experiments with a $\beta$-galactosidase target transgene demonstrated that the normal pattern of K14 expression was faithfully reproduced by the K14-tTA transgene. In addition, the level of tet-transactivator generated by this transgene was not toxic to mammary epithelial cells, target transgenes were not active in the absence of tTA, and target transgene expression was fully repressed in the presence of tetracycline. On the basis of our results, we believe that this binary transgenic system should be useful for future studies examining transient overexpression of target genes in the embryonic gland or specific targeting to the myoepithelial/cap cell population at specified times during mammary development.

To our surprise, we found that the defects in ductal branching during puberty in the K14-PTHrP mice were the result of embryonic exposure to PTHrP. These results are reminiscent of experiments in which transient embryonic exposure to steroid hormones caused alterations in mammary ductal development during puberty and beyond (Hoshino 1966, Hoshino \& Connolly 1967, Nagasawa et al. 1974, Mori et al. 1980). The effects of steroid hormones are believed to result, in part, from permanent alterations in the estrous cycle of exposed mice (Hoshino 1966, Hoshino \& Connolly 1967, Nagasawa et al. 1974, Mori et al. 1980). It is unlikely that our results were due to systemic changes in the double transgenic mice. We have previously shown that circulating PTHrP concentrations are not increased in $\mathrm{K} 14-\mathrm{PTHrP}$ mice (Wysolmerski et al. 1995). In addition, these transgenic mice cycle normally and display normal fertility (unpublished data), ruling out any gross changes in their hypothalamic-pituitary-gonadal axis. However, at present it remains unclear how transient exposure to local overexpression of PTHrP before birth leads to a significant reduction in ductal branching complexity at the time of puberty, some 3-6 weeks later. We know that PTHrP has profound effects on the fate of the mesenchyme during fetal mammary development (Dunbar et al. 1999, Foley et al. 2001), so one possibility is that exposure to PTHrP alters the ability of either the periductal or fatty stroma of the fat pad to support correct branching. Previous recombination experiments have demonstrated that mammary ducts will branch in different configurations when combined with different stromal partners (Sakakura et al. 1976, Daniel et al. 1984). Alternatively, transient exposure to PTHrP might permanently affect the ability of the ductal epithelial cells themselves to give rise to side branches. The effects of PTHrP on ductal branching appear to be caused by amino-terminal PTHrP, acting on the type $1 \mathrm{PTH} / \mathrm{PTHrP}$ receptor, for we have found similar defects in transgenic mice that overexpressed parathyroid hormone (Wysolmerski et al. 1995). Because this receptor is not expressed on embryonic mammary epithelial cells (Wysolmerski et al. 1998, Dunbar et al. 1998), it is unlikely that PTHrP would affect epithelial cells in a typical autocrine fashion. Another possible mechanism may be via an intracrine pathway, for recent data have suggested that PTHrP can be imported into the nucleus and alter cellular behavior through a still undefined mechanism (Henderson et al. 1995, Massfelder et al. 
1997, Aarts et al. 1999, Lam et al. 2000). Recombination and transplantation experiments examining different pairings of transgenic and wild-type epithelium and stroma will be necessary to determine if the effects of PTHrP on branching are due to a cell-autonomous or stromal effect (Weisen et al. 1999).

Our data suggest that, in addition to its effects during embryonic mammary development, PTHrP may also participate in the regulation of cell turnover in TEBs during puberty. We found that pubertal overexpression of PTHrP led to an increase in the basal rate of apoptosis within end buds, and it completely blocked the increases in end bud proliferation and decreases in end bud apoptosis observed in wild-type mice treated with exogenous estrogen and progesterone. A great deal of previous work has demonstrated that TEBs are the sites of active cellular turnover and differentiation during the pubertal growth of the mammary ducts (Russo \& Russo 1980, Williams \& Daniel 1983, Daniel \& Silberstein 1987, Sapino et al. 1990, Humphreys et al. 1996). Therefore, the changes in proliferation and apoptosis that we observed most probably explain the delay in ductal extension caused by excess PTHrP production within the end buds of our transgenic mice. These results are also consistent with previous experiments in which slow-release pellets of PTHrP implanted into the mammary fat pad stalled the advance of the terminal end buds in wild-type mice treated with estrogen and progesterone (Wysolmerski et al. 1995). In the pubertal mammary gland, the PTHrP gene is most highly expressed within the cap cells of the terminal end buds, and the PTH-1R gene is most highly expressed in the stroma immediately surrounding these structures (Dunbar et al. 1998). Although epithelial cells in TEBs do not appear to express the PTH-1R, these are the cells the proliferation, apoptosis, or both, of which is affected by PTHrP overexpression. Therefore, it would appear that PTHrP most probably acts indirectly, via the stromal cells. We believe that our results raise the possibility that PTHrP might normally act to modulate the effects of steroid hormones on the stromal cells surrounding the end buds, thereby restraining ductal extension. However, confirmation of this hypothesis will require the demonstration of reciprocal changes in TEB cell turnover in the absence of PTHrP expression.

Consistent with the above hypothesis, the linear growth of the mammary ducts during puberty appears to be primarily a function of estrogen acting on the stromal cells of the mammary fat pad (Silberstein et al. 1994, Bocchinfuso \& Korach 1997, Cunha et al. 1997). It is believed that estrogen modulates signaling by local growth factor networks responsible for governing cellular proliferation and apoptosis within the terminal end buds (Imagawa et al. 1990). Several signaling systems have been implicated as potential mediators of the effects of estrogen. These include the epidermal growth factor (EGF) family of ligands and receptors (Ankrapp et al. 1998, Sebastian et al. 1998, Luetteke et al. 1999, Weisen et al. 1999), insulin-like growth factor-1 (Kleinberg et al. 2000) and hepatocyte growth factor/scatter factor (Yang et al. 1995). In addition, transforming growth factor (TGF)- $\beta$ has been shown to be a potent inhibitor of end bud proliferation and ductal growth (Daniel et al. 1989, Robinson et al. 1991, Pierce et al. 1993). Furthermore, overexpression of TGF- $\beta$ in the mammary glands of transgenic mice produces a phenotype that is remarkably similar to that of the K14-PTHrP and K14-tTA/ Tet $_{\mathrm{O}}-\mathrm{PTHrP}$ mice (Pierce et al. 1993). If PTHrP does act in a negative feedback loop to restrain the proliferative effects of estrogen, one might expect that expression of PTHrP or its receptor would be modified by estrogen. Although estrogen has been reported to upregulate, downregulate or not change the concentrations of PTHrP in breast cancer cell lines (Kurebayashi \& Sonoo 1997, Funk \& Wei 1998, Sugimoto et al. 1999), we have found no evidence that hormone treatment affects levels of whole gland PTHrP or PTH-1R mRNA in early adolescent mice (unpublished results). However, it has been reported that the production of PTHrP by normal mammary epithelial cells in culture is enhanced by treatment with either EGF or TGF- $\beta$ (Ferrari et al. 1992, 1994, Sebag et al. 1994, Yin et al. 1999). More research will be needed to determine where PTHrP signaling might fit in the hierarchy of changes induced by steroid hormones in the terminal end buds.

In our original description of the K14-PTHrP mammary phenotype, we felt that the delay in lobuloalveolar development that we observed was a function of a defect in terminal duct formation, rather than a defect in lobuloalveolar differentiation per se (Wysolmerski et al. 1995). Our observations in the K14-tTA/Tet ${ }_{\mathrm{O}}-\mathrm{PTHrP}$ double transgenic mice support this interpretation. If we delayed the onset of transgene expression until after the duct system was formed, PTHrP overexpression had no effect on the development of lobuloalveolar structures during pregnancy. This suggests that the defects that we observed during pregnancy in the single transgenic mice were indeed related to pre-existing abnormalities in the ductal tree. We conclude that overexpression of PTHrP, at least within myoepithelial cells, does not inhibit lobuloalveolar differentiation.

In summary, we have developed a tetracyclineregulated PTHrP transgene that has allowed us to investigate the effects of $\mathrm{PTHrP}$ overexpression at specific times in the life cycle of the mammary gland. Using this approach we have learned that transient overexpression of PTHrP during embryonic mammary development reduced the capacity of the growing ducts to form side branches during puberty. In addition, overexpression of PTHrP during puberty itself slows the rate at which mammary ducts grow through the fat pad. This inhibition of ductal elongation is associated with an increase in the rate of cell death in terminal end buds and resistance to 
the proliferative and anti-apoptotic effects of exogenous hormones on end bud cells. Our results suggest that PTHrP may function in terminal end buds as a natural inhibitor of hormone-induced ductal growth during puberty.

\section{Acknowledgements}

The authors would like to thank Drs Charles Daniel and Robin Humphreys for helpful suggestions. We thank Dr Arthur Broadus for his critical reading of the manuscript. This work was supported by NIH grants DK55501, DK45735 and DK48108 and Department of Defense Breast Cancer Research Program grants DAMD17-961-9198 and DAMD17-97-1-7137.

\section{References}

Aarts MM, Rix A, Guo J, Bringhurst R \& Henderson JE 1999 The nucleolar targeting signal (NTS) of parathyroid hormone related protein mediates endocytosis and nucleolar translocation. Journal of Bone and Mineral Research 14 1493-1503.

Ankrapp DP, Bennett JM \& Haslam SZ 1998 Role of epidermal growth factor in the acquisition of ovarian steroid hormone responsiveness in the normal mouse mammary gland. Journal of Cell Physiology 174 251-260.

Bocchinfuso WP \& Korach KS 1997 Mammary gland development and tumorigenesis in estrogen receptor knockout mice. Journal of Mammary Gland Biology and Neoplasia 2 323-334.

Cunha GR 1994 Role of mesenchymal-epithelial interactions in normal and abnormal development of the mammary gland and prostate. Cancer 74 1030-1044.

Cunha GR, Young P, Hom YK, Cooke PS, Taylor JA \& Lubahn DB 1997 Elucidation of a role of stromal steroid hormone receptors in mammary gland growth and development by tissue recombination experiments. Journal of Mammary Gland Biology and Neoplasia 2 393-402.

Daifotis AG, Weir EC, Dreyer BE \& Broadus AE 1992 Stretchinduced parathyroid hormone-related peptide gene expression in the rat uterus. Journal of Biological Chemistry 267 23455-23458.

Daniel CW \& Silberstein GB 1987 Postnatal development of the rodent mammary gland. In The Mammary Gland, Development, Regulation and Function, pp 3-36. Eds MC Neville \& CW Daniel. New York: Plenum Press.

Daniel CW, Berger JJ, Strickland P \& Garcia R 1984 Similar growth pattern of mouse mammary cells cultivated in collagen matrix in vivo and in vitro. Developmental Biology 104 57-64.

Daniel CW, Silberstein GB, Van Horn K, Strickland P \& Robinson S 1989 TGF- $\beta 1$-induced inhibition of mouse mammary ductal growth: developmental specificity and characterization. Developmental Biology 135 20-30.

Dunbar ME, Young P, Zhang JP, McCaughern-Carucci J, Lanske B, Orloff J, Karaplis A, Cunha G \& Wysolmerski JJ 1998 Stromal cells are critical targets in the regulation of mammary ductal morphogenesis by parathyroid hormone-related protein (PTHrP). Developmental Biology 203 75-89.

Dunbar ME, Dann PR, Robinson GW, Hennighausen L, Zhang JP \& Wysolmerski JJ 1999 Parathyroid hormone-related protein is necessary for sexual dimorphism during embryonic mammary development. Development 126 3485-3493.

Ferrari SL, Rizzoli R \& Bonjour JP 1992 Parathyroid hormone-related protein production by primary cultures of mammary epithelial cells. Journal of Cell Physiology 150 304-311.
Ferrari SL, Rizzoli R \& Bonjour JP 1994 Effects of epidermal growth factor on parathyroid hormone-related protein production by mammary epithelial cells. Journal of Bone and Mineral Research 9 639-644.

Foley J, Dann P, Hong J, Cosgrove J, Dreyer B, Rimm D, Dunbar ME, Philbrick W \& Wysolmerski JJ 2001 Parathyroid hormonerelated protein maintains mammary epithelial fate and triggers nipple skin differentiation during embryonic mammary development. Development 128 513-525.

Funk JL \& Wei H 1998 Regulation of parathyroid hormone-related protein expression in MCF-7 breast carcinoma cells by estrogen and antiestrogens. Biochemical and Biophysical Research Communications 251 849-854

Furth PA, St Onge L, Böger H, Gruss P, Gossen M, Kistner A, Bujard H \& Hennighausen L 1994 Temporal control of gene expression in transgenic mice by a tetracycline-responsive promoter. PNAS 91 9302-9306.

Henderson JE, Amizuka N \& Warshawsky H 1995 Nucleolar localization of parathyroid hormone-related peptide enhances survival of chondrocytes under conditions that promote apoptotic cell death. Molecular and Cellular Biology 15 4064-4075.

Hennighausen L \& Robinson GW 1998 Think globally, act locally: the making of a mouse mammary gland. Genes and Development 12 449-455.

Hoshino K 1966 Development and growth of mammary glands of CBA mice prenatally exposed to progesterone. Anatomical Record 154360.

Hoshino K \& Connolly MT 1967 Development and growth of mammary glands of mice prenatally exposed to estradiol benzoate. Anatomical Record 157262.

Humphreys RC, Krajewska M, Krnacik S, Jaeger R, Weiher H, Krajewski S, Reed JC \& Rosen JM 1996 Apoptosis in the terminal endbud of the murine mammary gland: a mechanism of ductal morphogenesis. Development 122 4013-4022.

Imagawa W, Bandyopadhyay GK \& Nandi S 1990 Regulation of mammary epithelial cell growth in mice and rats. Endocrine Reviews 11 494-523.

Kleinberg DL, Feldman M \& Weifeng R 2000 IGF-1: an essential factor in terminal end bud formation and ductal morphogenesis. Journal of Mammary Gland Biology and Neoplasia 5 7-17.

Kurebayashi J \& Sonoo H 1997 Parathyroid hormone-related protein secretion is inhibited by oestradiol and stimulated by antioestrogens in KPL-3c human beast cancer cells. British Journal of Cancer $\mathbf{7 5}$ 1819-1825.

Lam MH, Thomas RJ, Martin TJ, Gillespie MT \& Jans DA 2000 Nuclear and nucleolar localization of parathyroid hormone-related protein. Immunology and Cell Biology 78 395-402.

Lee K, Deeds JD \& Segre GV 1995 Expression of parathyroid hormone-related peptide and its receptor messenger ribonucleic acids during fetal development of rats. Endocrinology 136 453-463.

Luetteke NC, Qiu TH, Fenton SE, Troyer KL, Riedel RF, Chang A \& Lee DC 1999 Targeted inactivation of the EGF and amphiregulin genes reveals distinct roles for EGF receptor ligands in mouse mammary gland development. Development 126 2739-2750.

McGrath CM 1983 Augmentation of the response of normal mammary epithelial cells to estradiol by mammary stroma. Cancer Research 43 1335-1360.

Massfelder T, Dann P, Wu TL, Vasavada R, Helwig JJ \& Stewart AF 1997 Opposing mitogenic and anti-mitogenic actions of parathyroid hormone-related protein in vascular smooth muscle cells: a critical role for nuclear targeting. PNAS 94 13630-13635.

Mori T, Nagasawa H \& Bern HA 1980 Long-term effects of perinatal exposure to hormones on normal and neoplastic mammary growth in rodents: a review. Journal of Environmental Pathology and Toxicity 3 191-205. 
Nagasawa H, Yanai R, Shodono M, Nakamura T \& Tanabe Y 1974 Effect of neonatally administered estrogen or prolactin on normal and neoplastic mammary growth and serum estradiol-17b level in rats. Cancer Research 34 2643-2646.

Philbrick WM, Wysolmerski JJ, Galbraith S, Holt E, Orloff JJ, Yang KH, Vasavada RC, Weir EC, Broadus AE \& Stewart AF 1996 Defining the roles of parathyroid hormone-related protein in normal physiology. Physiological Reviews 76 127-173.

Pierce DF, Johnson MD, Matsui Y, Robinson SD, Gold LI, Purchio AF, Daniel CW, Hogan BLM \& Moses HL 1993 Inhibition of mammary duct development but not alveolar outgrowth during pregnancy in transgenic mice expressing active TGF- $\beta 1$. Genes and Development 7 2308-2317.

Robinson SD, Silberstein GB, Roberts KC, Flanders KC \& Daniel CW 1991 Regulated expression and growth inhibitory effects of transforming growth factor- $\beta$ isoforms in mouse mammary gland development. Development 113 867-878.

Russo J \& Russo IH 1980 Influence of differentiation and cell kinetics on the susceptibility of the rat mammary gland to carcinogenesis. Cancer Research 40 2677-2687.

Sakakura T 1987 Mammary embryogenesis. In The Mammary Gland, Development, Regulation and Function, pp 37-65. Eds MC Neville \& CW Daniel. New York: Plenum Press.

Sakakura T, Nishizuka Y \& Dawe CJ 1976 Mesenchyma-dependent morphogenesis and epithelium-specific cytodifferentiation in mouse mammary gland. Science 194 1439-1441.

Sapino A, Macri L, Gugliotta P \& Bussolati G 1990 Immunocytochemical identification of proliferating cell types in mouse mammary gland. Journal of Histochemistry and Cytochemistry $\mathbf{3 8}$ $1541-1547$.

Sebag M, Henderson J, Goltzman D \& Kremer R 1994 Regulation of parathyroid hormone-related peptide production in normal mammary epithelial cells. American Journal of Physiology 267 C723-C730.

Sebastian J, Richards RG, Walker MP, Wiesen JF, Werb Z, Derynck R, Hom YK, Cunha GR \& DiAugustine RP 1998 Activation and function of the epidermal growth factor receptor and erbB-2 during mammary gland morphogenesis. Cell Growth and Differentiation 9 $777-785$.

Silberstein GB, VanHorn K, Shyamala G \& Daniel CW 1994 Essential role of endogenous estrogen in directly stimulating mammary growth demonstrated by implants containing pure antiestrogens. Endocrinology 134 84-90.

Smith GH, Mehrel T \& Roop DR 1990 Differential keratin gene expression in developing, differentiating, and neoplastic mouse mammary epithelium. Cell Growth and Differentiation 1 161-170.

Strewler GJ 2000 The physiology of parathyroid hormone-related protein. New England Journal of Medicine 342 177-185.
Sugimoto T, Shiba E, Watanabe T \& Takai S 1999 Suppression of parathyroid hormone-related protein messanger RNA expression by medroxyprogesterone acetate in breast cancer tissues. British Cancer Research and Treatment 56 11-23.

Taylor-Papdimitriou J \& Lane EB 1987 Keratin expression in the mammary gland. In The Mammary Gland, Development, Regulation and Function, pp 181-215. Eds MC Neville \& CW Daniel. New York: Plenum Press.

Weisen JF, Young P, Werb Z \& Cunha GR 1999 Signaling through the stromal epidermal growth factor receptor is necessary for mammary ductal development. Development 126 335-344.

Williams JM \& Daniel CW 1983 Mammary duct elongation: differentiation of myoepithelium and basal lamina during branching morphogenesis. Developmental Biology 97 274-290.

Wysolmerski JJ \& Stewart AF 1998 The physiology of parathyroid hormone-related protein: an emerging role as a developmental factor. Annual Review of Physiology 60 431-460.

Wysolmerski JJ, Broadus AE, Zhou J, Fuchs E, Milstone LM \& Philbrick WM 1994 Overexpression of parathyroid hormone-related protein in the skin of transgenic mice interferes with hair follicle development. PNAS 91 1133-1137.

Wysolmerski JJ, McCaughern-Carucci JF, Daifotis AG, Broadus AE \& Philbrick WM 1995 Overexpression of parathyroid hormone-related protein or parathyroid hormone in transgenic mice impairs branching morphogenesis during mammary gland development. Development 121 3539-3547.

Wysolmerski JJ, Philbrick WM, Dunbar ME, Lanske B, Kronenberg H, Karaplis A \& Broadus AE 1998 Rescue of the parathyroid hormone-related protein knockout mouse demonstrates that parathyroid hormone-related protein is essential for mammary gland development. Development 125 1285-1294.

Yang Y, Spitzer E, Meyer D, Sachs M, Niemann C, Hartmann G, Weidner KM, Birchmeier C \& Birchmeier W 1995 Sequential requirement of hepatocyte growth factor and neuregulin in the morphogenesis and differentiation of the mammary gland. Journal of Cell Biology 131 215-226.

Yin JJ, Selander K, Chirgwin JM, Dallas M, Grubbs BG, Wieser R, Massague J, Mundy GR \& Guise TA 1999 TGF-beta signaling blockade inhibits PTHrP secretion by breast cancer cells and bone metastases development. Journal of Clinical Investigation 103 197-206.

Zeps N, Dawkins HJS, Papadimitriou JM, Redmond SL \& Walters MNI 1996 Detection of a population of long lived cells in mammary epithelium of the mouse. Cell and Tissue Research 286 $525-536$.

Received 14 August 2001

Accepted 29 August 2001 